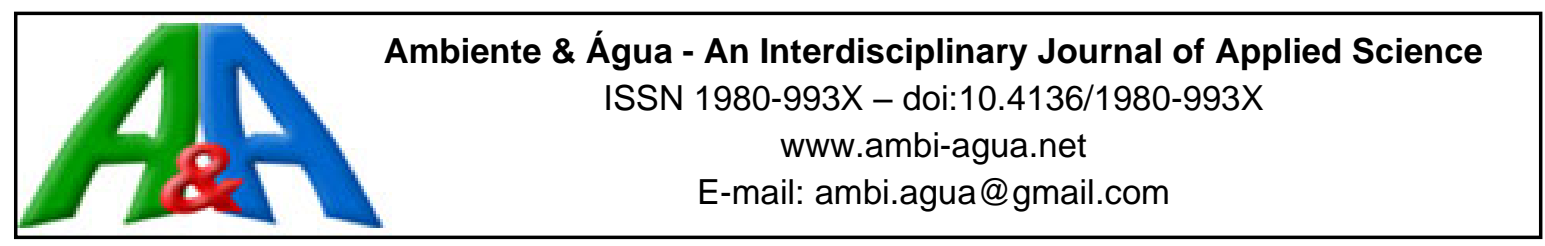

\title{
Case report: vegetable gardens in rural schools and environmental education
}

\author{
ARTICLES doi:10.4136/ambi-agua.2566
}

Received: 05 Out. 2020; Accepted: 09 Nov. 2020

\author{
Sylvia Helena Espíndola Salles $i^{D}$; Giovanna Brito Lins $i$ \\ Adriana Mascarette Labinas ${ }^{D}$; Maria Lúcia Paulino Silva Sousa ${ }^{(D}$; \\ Elisa Mitsuko Aoyama*iD; Marcos Roberto Furlan
}

\begin{abstract}
Programa de Pós-Graduação em Ciências Ambientais (PPGCA). Universidade de Taubaté (UNITAU), Estrada Municipal Doutor José Luiz Cembranelli, n5000, CEP: 12081-010, Taubaté, SP, Brazil. E-mail: syhespindola@hotmail.com, giovannabritolins@gmail.com, alabinas@uol.com.br, lucinhapaulino80@gmail.com, marcos.furlan@unitau.br

*Corresponding author. E-mail: elisa.aoyama@ufes.br
\end{abstract}

\begin{abstract}
In schools, a vegetable garden can enable the development of various pedagogical activities in environmental education and food reeducation, as it can unite theory and practice in a contextualized way. The objective of the present work was to implant gardens in rural municipal schools, analyze their potentialities as a didactic resource for the disciplines of elementary school and verify if they can contribute to environmental education and food reeducation. The gardens were planted at schools located in the rural area of the municipality of Taubaté, State of São Paulo. In addition to activities with teachers and students, there was also a demonstration of agricultural practices to community producers. After conducting vegetable garden-related activities with students, an analysis of the interaction with other subjects in the curriculum was carried out. As main results, it was observed that, in addition to connecting the theoretical concepts of the disciplines to the daily lives of students and the community, a vegetable garden at school assists in the development of content in a multidisciplinary way and promotes critical formation of students and teachers regarding the use of environmental and food resources. Observation of the participants related to the gardening activities supports the conclusion that the garden in the school environment significantly facilitated the development of themes related to environmental education and food reeducation.
\end{abstract}

Keywords: environmental sciences, interdisciplinarity, pedagogical activity, school gardens.

\section{Horta em escolas rurais e a educação ambiental: estudo de caso}

\section{RESUMO}

Nas escolas, uma horta pode possibilitar o desenvolvimento de diversas atividades pedagógicas em educação ambiental e reeducação alimentar, pois ela pode unir a teoria e a prática de forma contextualizada. O presente trabalho teve como objetivos implantar hortas em escolas municipais rurais, analisar as suas potencialidades como recurso didático para as disciplinas do ensino fundamental I e verificar se podem contribuir na educação ambiental e na reeducação alimentar. As hortas foram implantadas em escolas localizadas na zona rural do 
município de Taubaté, Estado de São Paulo. Além das atividades com docentes e alunos, também ocorreram demonstração das práticas agrícolas aos produtores da comunidade. Após a condução da horta e das atividades com os alunos, foi realizada a análise da interação com outras disciplinas do currículo. Como principais resultados, observou-se que além de conectar os conceitos teóricos das disciplinas ao cotidiano dos alunos e da comunidade, uma horta na escola constitui uma estratégia capaz de auxiliar no desenvolvimento dos conteúdos de forma multidisciplinar e de promover uma formação crítica dos alunos e dos professores frente ao uso dos recursos ambientais e alimentares. A partir da observação de todos os participantes durante a execução das atividades, pode-se concluir que a horta no ambiente escolar serviu como elemento capaz de proporcionar o desenvolvimento de temas referentes à educação ambiental e à reeducação alimentar.

Palavras-chave: atividade pedagógica, ciências ambientais, interdisciplinaridade.

\section{INTRODUCTION}

The family environment and the school are privileged places for environmental education practices. Environmental issues must therefore be addressed in both places, and these are also favorable environments in which to develop nutritional education strategies, because, in addition to serving schoolchildren, they can involve the family and the community (WHO, 2006).

Bragato et al. (2018) highlighted the importance of the teacher as an instrument to train citizens with the capacity to develop critical visions and to transform the environment where they live. These authors also added that extension activities have great value, because with them communities can participate and work with themes of their daily lives.

In schools, a vegetable garden enables the development of various educational activities in environmental education and food reeducation, as it unites theory and practice in a contextualized way. The vegetable garden strengthens relations by promoting collective work and cooperation among the social agents involved, and helps in the teaching-learning process (Morgado and Santos, 2006).

Environmental education must be inserted in the elementary school curriculum and must be taught in an interdisciplinary way, as it seeks to contextualize with local realities. Da Costa et al. (2015) found that the combination of an environmental education project with a vegetable garden provided studies based on various areas of knowledge, and afforded contextualized learning that assisted in the formation of conscious and critical citizens cognizant of environmental issues.

For Da Costa et al. (2015), the vegetable garden at school can be considered an experimental laboratory, as it stimulates students to carry out scientific research and promotes quality education within the school environment. The authors add that there is an improvement in the teaching-learning process; the experience strengthens the theme of sustainable development and makes it possible for students to take this proposal to their homes, with the possibility of replicating the project and improving the quality of life of their family members.

The vegetable garden can also enhance interdisciplinary learning. Gallo (2000, p. 6) observed that:

The general sense of interdisciplinarity is the awareness of the need for an explicit interrelationship between all disciplines. In other words, interdisciplinarity is the attempt to overcome a historical process of abstraction of knowledge that culminates in the total disarticulation of knowledge that our students (and also we, teachers) are unhappy with experiencing (Gallo, 2000, p. 6). 
As a component of nutritional education, vegetable gardens can increase knowledge about fruits and vegetables and induce behavioral changes among children. Parmer et al. (2009) suggested that school administrators, teachers and nutrition educators, should implement school gardens as a way to positively influence eating habits at an early age.

In view of the above, the present study implemented vegetable gardens in rural schools located in the municipality of Taubaté, State of São Paulo, aiming to analyze their potential as a didactic resource for elementary school subjects, in addition to assisting in the environmental education and food reeducation of students.

\section{MATERIALS AND METHODS}

The project was developed at José Marcondes de Moura Municipal School of Early Childhood Education (EMEIEF), Monjolinho District and José Rubens Wauner de Campos Municipal School of Primary Education (EMEF), located in the Pouso Frio District, municipality of Taubaté, State of São Paulo.

The work was developed together with the "Agronomy at School" Project, prepared by the Center for Studies and Research on Medicinal, Aromatic and Spice Plants of the Department of Agricultural Sciences, University of Taubaté - UNITAU, Taubaté, São Paulo.

The first vegetable garden was planted at EMEIEF José Marcondes de Moura, and the second vegetable garden at EMEF José Rubens Wauner de Campos. In both, training was provided on how to set up the garden for teachers, students and staff. Basic notions about agricultural and biological sciences were also provided, and the knowledge was passed on to family members and the community.

In the guidelines on planning and conducting the vegetable garden, theoretical and practical classes were carried out, including models made by the students. The activities aimed at elementary school students who required writing were done as follows: 1st and 2nd year students who did not know how to write were paired with 3rd and 4th year students who already knew.

As an evaluation of the project, whether or not the activities managed to relate to the pedagogical content of the subjects was analyzed.

\section{RESULTS AND DISCUSSIONS}

Tables 1 and 2 show, respectively, the examples of content taught and discussed in the training.

Table 1. Content taught during training for teachers and students.

Verification of geographic location through cardinal points and latitude, aiming at the correct location of the vegetable garden;

Soil recognition through spontaneous plants, coloring and other characteristics;

Recognition of spontaneous flora that, despite being considered harmful, can provide uses such as food, indication of soil and attraction or repellency of pests;

Information on leaf-cutting ants, such as: saúvas and quenquéns;

Production of organic compost using organic waste from the school itself and with the objective of producing compost for the garden;

Formation of flower beds; and

Vegetable plantation and medicinal plants.

Source: Authors (2020). 
Table 2. Content discussed with students.

\begin{tabular}{l} 
The attack of the ants, and how to combat them in a natural way; \\
\hline About termite, bee and ant teamwork; \\
The difference between the ant saúva and quenquém; \\
The feeding of ants, which are fungi; \\
Caterpillar attacks, which can be combated with biological control.
\end{tabular}

Source: Authors (2020).

Among the contents are examples of information received: the presence of a single species of vegetable is indicative of fresh soil, while the occurrence of several species and mainly of the broad-leaved type (dicotyledons) indicates better soil; a bad soil if well worked will change the flora, that is, narrow leaf species (monocotyledonous) will disappear and broadleaf species will appear. In addition to the inclusion of this knowledge in botany, this information was considered useful for parents to evaluate their property.

Regarding the choice of tools, it was highlighted that they must be compatible with the student's size, as well as the width of the flower bed. It was shown that the level of the flower bed can be checked using a PET bottle. In addition to the question of ergonomics, for elementary school students, these subjects were applied in mathematics.

Some notions of asexual or agamic propagation were shown, such as, for example: manioc, by branch cuttings; cabbage, by sprouts in the armpits; chives, by clump division and sweet potatoes, by branch.

Students received guidance on how to make a composter with the dimensions $1.0 \mathrm{x} 1.0 \mathrm{x}$ $1.0 \mathrm{~m}$, which may result in $700 \mathrm{~kg}$ of compost, and to add chopped green materials to provide better action by the decomposing microorganisms. It was recommended that products that contain a lot of tannin and essential oils not be placed there, because these inhibit the proliferation of bacteria in organic compounds, such as banana peels or orange peels.

At the end, certificates conferred upon students who participated in the formation and care of the garden.

At the EMEF José Rubens Wauner de Campos - Pouso Frio school, a visit was made with students and teachers in the surroundings of the school to look for edible plants, and a contest was also conducted to see who could find more specimens of plants, and also in order to show the difference between one leaf and another ("wide or narrow"). Table 3 shows the number of edible plants found by the students, demonstrating important knowledge related to the harveste of unconventional food plants.

Table 3. Number of unconventional edible spontaneous plants indicated by students.

\begin{tabular}{cc}
\hline Grade & Number of leaf samples found \\
\hline 1st and 2nd & 20 \\
3rd and 4th & 12 \\
\hline
\end{tabular}

Source: Authors (2020).

During the formation of the vegetable garden at the EMEF José Rubens Wauner de Campos school, the recognition and measurement of the area and collection of soil samples to be analyzed was carried out. Portions of sand had to be incorporated into the soil to aid drainage, as well as tanned manure to increase nutrients.

After training to form the garden, following discussion and agreement with teachers and principals, activities directly related to the disciplines were initiated. 


\subsection{Portuguese}

The students used ways of reading and interpreting texts, reinforcing spelling, with specific themes on the formation of gardens.

To begin to understand the importance and appreciation of their local environment, several stories were told:

- "Aventuras no Sítio do Picapau Amarelo" (Molinaro, 2003);

- "Lembranças que o tempo não apaga" (Salgado, 2004);

- "O Rato do Campo e o Rato da Cidade" (Moral, 2018).

The latter reports:

There was a mouse that lived on the farm and the mouse that lived in the city. The town's mouse came to visit the farm's, finding it strange that only cereals were served to eat, making the farm's mouse very ashamed, as it was only what it had to offer. Another day the little mouse from the farm went to visit the little mouse in town, getting there he was enchanted with everything he saw: the huge house, the well-kept garden, and when he saw the table set up and full, he didn't think and soon wanted to start eating all that! However, the city mouse stopped him by saying that he was to be careful because the owners could arrive. There was nothing else: two huge cats soon appeared! They had to run a lot to avoid being eaten. The farm mouse was so scared that he preferred to return where he came from because he didn't have all those plentiful things, but he never went hungry and much less the risk of being eaten alive (Moral, 2018).

At the end, they produced a text with the theme: "The importance of healthy eating".

\subsection{Mathematics}

The importance of calculations in the construction and organization of flower beds was highlighted, in addition to calculating food waste using the four fundamental operations and comparing product prices.

\subsection{Natural Sciences}

Pollution of the environment and the time that each type of waste takes to decompose was discussed with the students, making a relation, for example, between the difference of the papers that can be recycled. The panel on the decomposition time of the materials served as a basis to be used when assembling the composter. Drums painted with the color pattern of the signage of each material to be recycled, for disposal to occur correctly were donated to the school by Rotary Oeste from Taubaté: Blue - Paperboard and Paper; Red - Plastic; Green Glass; Yellow - Metal (CONAMA, 2001).

Regarding the importance of living beings that exist in the garden, there were discussions identifying which would be the "good and bad bugs" that are part of that environment and that should not be removed from there, since there are special techniques so that they can continue to live there without harming the vegetable garden. Afterwards, a new tour was carried out to visualize these living beings and, to emphasize the subject, strategies such as the construction of a herbarium containing species of broad and narrow leaves were used.

The difference between broad leaves and narrow leaves was recalled in more detail, for example, showing the bean seed that has two parts, so the leaf would be wide, while the corn seed has only one, so the leaf would be narrow. From the first, two leaves sprout, and from the second, only one. To this end, the students planted both seeds in plastic cups with soil, observing how they reacted to the excess or lack of water over time until germination (about 15 days); 
after that period, the seedlings were taken for domestic planting by students and families.

\title{
3.4. Geography
}

Students studied the soil, vegetation, climate, temperature, solar rotation and cardinal points. A model of the place was made between teachers and students and guidance was given on solar rotation, factors associated with planting and development of the garden's plants.

\subsection{History}

Ethnic groups, customs and legends were discussed, assuming that the young person only builds his history with the experiences of their ancestors and that this link can also be provided with stories of the use of medicinal plants, as in the text "A Escola Pouso Frio" (Salgado, 2004, p. 39).

In 1942, the Portuguese who came to explore the graphite plant left. That year, Geraldo Marcondes married Professor D. Lígia de Moura Santos, daughter of the professor and writer Máximo de Moura Santos. The couple moved to the farm and, over time, had two children: José Geraldo and Carlos Máximo.

In 1943, they opened a school on the farm. It was installed in a wooden shed left by the Portuguese. They removed the partition and made a huge classroom. It was called the Mixed School of Bairro do Pouso Frio and was attended by 38 students. Mr. Nenêco, alone, had nine children at school.

Mrs. Ligia was a teacher very dedicated to her students. On special days, she "organized many parties, with great affection."

Another story passed on in order to highlight ancestral experiences with medicinal plants was the "Aventuras no Sítio do Pica-pau Amarelo" - Tia Nastácia e o Folclore (Molinaro, 2003, p. 30):

\begin{abstract}
Mr. Lobato was the owner of the farm and due to the difficult access of the people to the villages, to the town's doctors and pharmacies, his children and employees were cured by the remedies made by the strong tradition of home medicine that he himself indicated, but he always consulted the doctor book entitled Chernoviz, which based on the symptoms, indicated the diagnosis and the remedy for the case. Some settlers never let their gardens and gardens be lacking as quicker herbs, such as: Alfavaca, delicious in the seasoning of fish, this plant, in infusion, is good for cold sore and sore throat, rinsing and gargling; Boldo, say that rinsing the infusion reduces the urge to smoke and that tea is very good for curing bad digestion; Lemon balm, tea, besides being soothing, is good for flu; Fennel, cakes and sweets are great with fennel and their tea is very good for relieving gas in the stomach; Mint, the tea, delicious, is soothing and gives a special flavor to juices, salads and meats. (Molinaro, 2003, p. 30).
\end{abstract}

\subsection{Art}

Music, theater, cooking and handicraft workshops were created with organic gardens and medicinal plants.

Songs like "Água da Biquinha", "Meu lanchinho", were taught to be sung every day at snack time. "A Cabeça", whose lyrics were designed to encourage them to value studies, curiosities and discoveries. Expository classes, research exhibits, practical classes and panel making were conducted with the families.

\subsection{Religious education}

In this curricular axis, the issue of respect for the knowledge of cultures that use, based on popular tradition, medicinal herbs for various treatments was included. To work on the item 
"respect", the conversation wheel between students was used to debate what their parents know how to do (profession) and what students perceived as family learning.

In addition, it was about respecting nature and its resources: "Let us respect nature, because it gives us gifts in many ways". With this phrase, the students exposed, through the conversation wheel, the different ways they know about nature in our daily lives.

\subsection{Interactions with parents}

There was a day of great meeting between parents, representatives of Taubaté City Hall, Rotary and representatives of UNITAU, with the purpose of showing works done by students.

A playbook about "A Sementinha" was presented, made by students from 1st to 4th years:

\section{Jogral}

(*) one student (-) boys (+) girls

A Sementinha (Educar para colher o bem, 2014).

1) *The wind threw me to the ground ...

What a fright I got!

I sank into the soft land,

And there, quietly, I stayed.

2) - The rain later fell,

+ Small, without ceasing.

The earth was cool,

I started to swell ...

3) *After quenching my thirst,

I tried to work.

To stand on the ground,

-I told the root to sprout.

4) + It came out very slowly

And on the ground it spread.

-Then the stem, greenish,

The terrain has drilled.

5) + Up, up, lightly,

-And the leaf came out.

*Now I'm a bud,

The seed has germinated!

The song "O Sítio do Senhor Lobato" was divided into classes for the choir, where each group imitated the sound of the animals.

Some comments were made about the work being developed at the school, the moment was taken to make the parents try to remember some old toys that were made by themselves.

Tree Day was also celebrated and the entrance of Spring; tree seedlings were planted by students, donated by the Municipality of Taubaté, Rotary and UNITAU.

Finally, on this day, culinary exchanges were made only with spontaneous edible plants and alternative foods provided by UNITAU and brought by parents. 
The implementation of the garden involved not only students, but also several sectors of schools, in addition to families and the community, emphasizing the importance and richness of human and environmental interactions in the teaching-learning process. This corroborated the argument of Da Costa et al. (2015), that the school is an adequate space to improve learning in the theoretical and practical fields of this theme and that students, from the information provided to them, can become agents of transformation of a society. The teacher is fundamental in this training, and facilitates the attainment of the students' highest intellectual and artistic potentials.

Interdisciplinarity was fundamental for the discussion, organization, application and operation of the project. Thus, this interdisciplinarity can provide, as Gallo (2000) argues, the construction of a conception of knowledge that sees multiplicity without fragmentation; a curriculum and a school in which children can learn about the world in which they live, a multiple world full of surprises, and can master the different tools that allow their access to the knowledge made possible by that world, and can learn to relate with others and with the world at large.

The curricular component of the Portuguese literary works showed the students that, although they live far from the cities and everything is very simple, there is plenty of food when the cultivation and preservation practices are understood. Mathematics was present in all structural and planning aspects of the garden, requiring, in a simple way, operations that were basic and very logical - a fundamental factor for the development of intellectual capacities.

The observation of natural phenomena in practice was (during sowing attributed to the Natural Sciences, for example) quite rich, because it relates theory to practice, corroborating different skills and introducing scientific methodologies in childhood, such as observation, hypothesis survey, research, tests and rationale. It also facilitates an understanding of the environment surrounding them and the role students play as citizens capable of transforming it. Exercises associated with waste recycling illustrated these aspects also. The activities and contents relating to Geography also fit well. The orientation of the flower beds on the school grounds was used as an example to help in understanding the environment from a theoretical and scientific basis: the beds were placed to the north so that the plants received more sunlight, and the species chosen, in addition to the study of soil, varieties, climate and temperature, facilitated the best development of the vegetable garden.

In regard to History, the importance of understanding the role of the individual in space, but also over time, was emphasized, extolling popular customs and knowledge also with scientific evidence, such as the use of medicinal plants that remain culturally alive today so that students may now relate to them with pride and criticality.

In the Arts component, in addition to the motor and sensory abilities worked on, songs brought references to what was worked on in the other components and information brought by the project (importance of understanding food, eating in a healthy way, etc.). Games and interactions between family, community, school, students, organizers and contributors to this study have strengthened human relations with the project.

\section{CONCLUSION}

In the conditions of carrying out this project, the conduction of a vegetable garden as a pedagogical tool with students, teachers and the community of the municipal schools EMEIEF "José Marcondes de Moura" and EMEF "José Rubens Wauner de Campos" (Taubaté-SP) proved to be an effective tool for transforming school spaces into spaces of environmental awareness and interaction.

Students, from an early age, proved capable of integrating knowledge from different areas, practicing new skills and developing a high sense of belonging to that community that has 
rediscovered itself rich in values, tradition and history. On the other hand, the school community can regard the Center for Studies and Research on Medicinal, Aromatic and Spice Plants of the University of Taubaté as a participative part of their daily lives, a catalyst of transformations and a partner in the generation and spreading of knowledge.

\section{REFERENCES}

BRAGATO, M. et al. A água e a saúde no meio rural. Educação ambiental nas escolas. Expressa Extensão, v. 23, n. 1, p.74-82, 2018. https://doi.org/10.15210/ee.v23i1.12492

CONAMA (Brasil). Resolução nº 275 de 25 de abril de 2001. Estabelece o código de cores para os diferentes tipos de resíduos, a ser adotado na identificação de coletores e transportadores, bem como nas campanhas informativas para a coleta seletiva. Diário Oficial [da] União: seção 1, Brasília, DF, n. 117-E, p. 80, 19 jun. 2001.

DA COSTA, C. A. G.; SOUZA, J. T. A.; PEREIRA, D. D. Horta escolar: alternativa para promover educação ambiental e desenvolvimento sustentável no Cariri Paraibano. Polêmica, v. 15, n. 3, p. 01-09, 2015. https://dx.doi.org/10.12957/polemica.2015.19350

EDUCAR PARA COLHER O BEM. Plano de aula. 26 ago. 2014. Available at: http://educarparacolherobem.blogspot.com/2014/08/de-aula-i-identificacaoescolae.html. Access: 14 Sep. 2020.

GALLO, S. Transversalidade e educação: pensando uma educação não-disciplinar. In: ALVES, N.; GARCIA, R. L. (Orgs.) O sentido da escola. Rio de Janeiro: DP\&A, 2000.

MOLINARO, C. F. Aventuras no sítio do Picapau Amarelo: tia Nastácia e o folclore. São Paulo: Globo, 2003. 64 p.

MORAL, S. O rato do campo e o rato da cidade. Madrid: Santillana, 2018. 16 p.

MORGADO, F. S.; SANTOS, M. A. A. dos. A horta escolar na educação ambiental e alimentar: experiência do projeto Horta Viva nas escolas municipais de Florianópolis. Extensio: Revista Eletrônica de Extensão, n. 6, 2006.

PARMER, S. M. et al. School Gardens: An Experiential Learning Approach for a Nutrition Education Program to Increase Fruit and Vegetable Knowledge, Preference, and Consumption among Second-grade Students. Journal of Nutrition Education and Behavior, v. 41, n. 3, p. 212-217, 2009. https://doi.org/10.1016/j.jneb.2008.06.002

SALGADO, M. A. Lembranças que o tempo não apaga. [Sl: sn], 2004.

WHO. Nutrition - Friendly Schools Initiative Conceptual Frame Work. Genebra, 2006. 